\title{
ISLAMIC ETHICS BASED ON AL-QUR'AN AND MULLA ȘADRĀ'S ESCATOLOGY
}

\author{
Kerwanto \\ STIF Sadra Jakarta \\ kerwanto@gmail.com
}

\begin{abstract}
Mulla Șadrā is one of the philosophers who provide philosophical views and answers to the principles of eschatology (ma'âd) that have not been answered by the philosophers of his predecessors. He is also known for successfully pouring his philosophical thoughts in his various commentaries on the main religious sources, both those relating to the Qur'an and hadīth. In this paper, there are several principles of eschatology of Șadrā which the writer will examine as the position of Șadrā in regard to post-mortal physical resurrection, the intellectual (intellectual) (intellectual), the role of the Actor (fâ'il) and Action ('amal) and the relationship between resurrection (ma'âd) and ethics (Akhlāk). In the eschatology of Șadrā, the knowledge of eschatological matters (life akherat) has a major influence on an individual's ethical actions. This paper is also intended to show that Mulla Șadrā's ethics as an implication of his eschatological philosophy is synergistic with the main sources of religion; Both the Qur'an and the Hadith of the Prophet.
\end{abstract}

Keywords: Mulla Șadrā, resurrection, ma'ād, eschatology, physical awakening (al ma'ād al jismānī), practical reason ('amalī), and theoretical reason (naẓarī).

\section{A. Introduction}

7 he human soul with its fitrah is created to love eternity and hate nothingness (extinction). If it is assumed that this life is limited to the life of this world alone, then it is not in accordance with the divine wisdom. Especially if we look at the reality of the life of this world; We will find so many different disasters and distresses in the world. There is no doubt, then, that the desire and love of eternity are the fittings of every human being that God has put into existence. Love of immortality will be the driving force toward immortality and encourage it to always be in motion. Therefore, the tendency toward eternal love is in harmony with the divine wisdom. And if there is another life that is eternal, surely not this material world as the phenomena we see in this world that 
everything will end with death (destruction of matter). In Asfār, Șadrā provides an argument about the existence of the resurrection day (ma'ād) by using such divine wisdom argument. ${ }^{1}$

Based on this brief explanation, it becomes clear to us that eschatology (post-death resurrection / ma'ād) and its discussion have a very important significance. In fact, the belief in tauhīd without being followed by a belief in eschatology / ma'ād will not have a significant effect and effect in directing a person to a righteous and purposeful life. It is, therefore, Islam's belief in eschatology (ma'âd) as one of the most important principles in belief.

Therefore, the discussion of the reality of eschatology (ma'ād), its relation to the life of the world and the influence of human actions during the life of the world to its happiness or misery later (akherat life) based on the point of view of transcendental philosophy Mulla Sadrā interesting to be studied further. This discussion is interesting considering that Mulla Șadrā other than as a philosopher, he also wrote several treatises of the Qur'an. Some of the risālah is collected by Muhammad khājavī into seven volumes, and is named with 'tafsīr al qur'ān al karīm'.

\section{B. Mulla Șadrā and His Thought on Eschatology}

1. The Rise of Physical and Spiritual material of Body (Jasmānī and Rūhānī)

One of the most important issues in religion is belief in physical resurrection (al ma'âd al jismānī). Philosophers have differed views on the subject; What is raised is the soul (soul) alone or both (the spirit and body)? Related to this question, Sadrā is different from Ibnu Sīnā. If Ibn Sīnā holds that only the soul is raised, then Sadrā believes in the resurrection of both. ${ }^{2}$ This view of Șadrā is in harmony with the verses of the Qur'an

$$
\begin{aligned}
& \text { ويقول الإنسان أئذا ما مت لسوف أخرج حيا. أولا يذكر الإنسان أنا خلقناه من قبل ولم يك شيئا }
\end{aligned}
$$

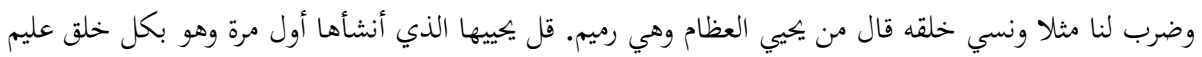

In his tafsir, Șadrā states:

"Our belief in the collection of bodies on the day of the akherat that he raised from the grave in the form of the body, and if you see one of them, then you will say he 'fulan' ... The resurrected in ma'âd is the soul and body, not just the soul Just as peripatetic views, or souls with other bodies as the views of other schools of thought, or not the body of mithali as the views of the followers of Sheikh Ishrāq. This is the right belief in accordance with reason and shari'a. Whoever justifies and believes in ma'ad, then he has faith with the day of resurrection, reckoning and recompense (jazā') so that he becomes an essential believer ...". ${ }^{3}$

\footnotetext{
${ }^{1}$ Ṣadrā, Al-Hikmah al-Muta 'āliyah fì al Asfār al- 'Aqliyah al-Arba 'ah, (Beirut: Dār iḥyā' al turāth, 1981), J. 9, 241

${ }^{2}$ Ibnu Sīnā, al-Najāh, (Tehran, 1985), 291.

${ }^{3}$ Șadrā, Tafsīr Al-Qur'ān al-Karìm, (Qum: Intishārāt Bīdār, 1344 H), J. 6, 73.
} 
The same thing will also be found in some other books, for example:

"The physical awakening (ma'ād jismanī) is due to this man having the spirit and the body that will return to the akherat, so that when one sees it in mạnshār, he says," this is the first time in the world. "Whosoever denied this, The main pillar of the faith so that he became a kafir by reason and shari'a. This means that he denies many nas and belongs to atheists and dahriyyah, including those who are not regarded as philosophers and nor are they made reference in thinking ('aqliyāt). They have no part in the Shari'a. They are the ones who deny the resurrection of the body and soul. Among them there are those who argue that if a person dies then he vanishes. He will not be revived. They are the most despicable people. Dinukil of Galenus about the absence of commentary on ma'ād because of his doubts in this mental affair, whether he is a mixture that will vanish or is an abstract form so it will be eternal ". ${ }^{4}$

The argument of Șadrā's belief in this physical and spiritual awakening is extensively reviewed by Sadrā in the asfär chapter nine $9 .^{5}$ In the book, we examine at length the basic principles for the provision of physical and spiritual awakening. The result of Sadrā's conclusion of this bodily resurrection is composed of a set of basic (basic principles of philosophy), such as the motion of substance (harakah jauhariyah), the fundamentality of being (așālah al wujūd), the being one but graded (tashkīk al wujūd), and ittihād al Aql, al aqīl wa ma'qūl.

This view of this physical and spiritual awakening is not a new view of Șadrā. This view is adopted by Șadrā from the Qur'an, the Sunnah and some of the previous 'god' (ie divine philosophers) such as Ibn Arabi. ${ }^{6}$

Furthermore, outline of the debate on the question of resurrection (ma'ād), Șadrā divides it into four classes, among them; (1). Spiritual awakening alone. This is the opinion of the majority of philosophers before Șadrā. (2). Physical awakening is the opinion of some theologians and fuqahā'. (3). Reject the resurrection. This is an atheist and a mul'd opinion. (4). Physical and spiritual resurrection is the opinion of the'urafā and the divine philosopher. ${ }^{7}$ According to Șadrā, the last group is the most correct opinion. ${ }^{8}$

\footnotetext{
${ }^{4}$ Ṣadrā, Manifestasi-Manifestasi Ilahi, (Jakarta: Press, 2011), 80 - 81; Ṣadrā, Al Mazāhir Al Ilāhiyyah fì Asrār al 'Ulūm al Kamāliyyah, (Tehran: Bonyad Hikmat Sadra Publishers), 125 - 126.

${ }^{5}$ Șadrā, Al-Hikmah al-Muta àliyah fì al-Asfär al- 'Aqliyah al-Arba 'ah, (Beirut: Dār ihyyā' al turāth, 1981), J. 9, $185-199$.

${ }^{6}$ Șadrā, Mafātih al-Ghayb, (Tehran: Cultural Researches Institution, 1982), 604 - 605.

${ }^{7}$ Șadrā, Al Mazāahir Al Ilāhiyyah fì Asrār al 'Ulüm al Kamāliyyah, (Tehran: Bonyad Hikmat Sadra Publishers), 85.

${ }^{8} I$ Ibid., 85; Șadrā, Tafsīr Al Qur'ān ..., J. 6, 73.
} 
Related to the resurrection of the body and soul (spirit), Șadrā insists, the body will be the body of the world akherat this body but the akherat has the perfection and strength of being. Such bodies are referred to as al badanal mithā $I i^{9}$

Human beings in afterlife will be the same human beings living in the world today. This is because the ownership of the individual's identity lies in the human psyche. The human soul remains awake despite damage and death to the body. As we have seen that a person's identity is maintained despite the many changes in body parts during life in the world. $^{10}$

\section{The Connection between Intellect with the Resurrection (Ma'ād)}

The intellect (intellect) in the concept of eschatology Șadrā has such an important value. According to Sadrā, the body's intelligence is the soul. Meanwhile, the soul's intelligence is intellect and intellect is the union with God. ${ }^{11}$ Evidently, the intellectual aspect of each soul has two functions: practice ('amalī) and theoretical (naẓarī).The intellectual practice ('amalī) has four stages: practicing the laws of religion, emptying the soul from all its filth, further illuminating it with knowledge and virtue and finally, it happens, fanā 'in God. ${ }^{12}$

While the theoretical sense (nazarī) also passes through four stages: the potential intellect (al'aql bil quwwah), which has a potential intellectual existence as a primary material having a potentially sensitive existence, capable of only accepting various forms called'aql al hayūlāni. The second stage is called the possessive intellect (al'aql bil malakah) in which the soul understands something simple (simple / basiț), self-explanatory truths. The third stage is called the actual intellect (al'aql bi al-fi'il) in which the soul transcends the material level of existence and gains intellectual intuition. The fourth (final) step is the enlightened intellect (al'aql al mustafād). This stage is the highest stage achieved by humans. The soul becomes intellect as a whole and gains companion with the active intellect (intellectual) and gains the intellectual (intelligible) intuition and gains access to the Kingdom of God. ${ }^{13}$

The ideal example of the perfection of the two minds is in the soul of the prophet Saw. In general about the characteristics of a prophet, in his tafseer Șadrā describes as follows:

"The parameters of the perfection and the glory of the prophet are not related to the body and substance of the material, but to the soul and soul. The perfection of the prophet's soul can be seen from two sides: first, the focus of the prophet's soul on God.

\footnotetext{
${ }^{9}$ Șadrā, Tafsīr Al-Qur'ān ..., J. 6, 73 - 74.

${ }^{10}$ Șadrā, Al-'Arshiyah, (Tehran, Mawla Publishers, 1984), 249 - 250.

${ }^{11}$ Șadrā, Al-Hikmah al Muta'āliyah ..., 347, 359.

${ }^{12}$ Ṣadrā, Al-Shawāhid al Rubūbiyah fì al Manāhij al Sulūkiyah, (Mashhad: al markaz al jami’ li al nashr, 1981),207.

${ }^{13}$ Ibid.
} 
It is called the theoretical faculty (speculative ability), ie; A perfection with respect to the very nature of the soul of the prophet and the return of that holy soul to God and the abstract realms ofālam mujarrād". ${ }^{14}$

The perfection of the theoretical reason possessed by prophet Muhammad is implied by the Qur'an Surah Al 'A'lā: 6-7.

$$
\text { سنقرؤك فلا تنسى. إلا ما شاء الله إنه يعلم الجهر وما يخفى (الأعلى/ ب- (V) }
$$

"We will recite (the Qur'an) to you (Muhammad) then you will not forget. Unless Allah wills.Verily He knows the light and the hidden. (Al 'A'la / 87: 6-7)."

While the perfection of the self-consciousness of the prophet Muhammad is implied by the Qur'an Surah Al 'A'lā: 8.

"And We will ease you to the easy way. (Al 'A'la / 87: 8)."

$$
\text { ونيسرك لليسرى (الأعلى/ ) م }
$$

Thus, the human soul according to the above division will be awakened (mahshūr) to the intellect and the intellect will be raised to God. ${ }^{15}$ With this principle, every human being should be aware of his intellect, for without his return to God is impossible. Although Șadrā greatly emphasizes intellectual awareness as Ibn Sīnā, but as the previous discussion that the resurrected (mu'âd) is not a rational body (akliyah) as perceived by the Peripatetic philosopher Ibnu Sīnā. In the view of Șadrā, the resurrected (mu'ād) is a continuous body of mithāl ((al muttașil) with the power of human imagination since life in the world.

On the contrary, the greatest obstacle for the soul to realize its intellect is $\sin .{ }^{16} \mathrm{Sin}$ can arise out of ignorance, therefore Șadrā states: "sin and evil follow the ignorance (al jahl al murakkab), while all good follows the science". ${ }^{17} \mathrm{He}$ pointed out that: "the anguish of ignorance is more severe than the suffering of bodily disobedience". ${ }^{18}$ This can happen because science (knowledge) is identical with the form itself. So the happiness and suffering associated with that level of knowledge are more essential (dhātī). Related to this, Șadrā states:

"Science is heaven, whereas ignorance (jahl) is hell. Peak enjoyment is on the perception of what he loves. On the contrary, the peak of suffering is far away from what he loves ... the perfection and enjoyment of the human soul lies in the eternal al ma'qūlat perception like the Dhāt of God, șifāt and 'af'al His ... ". ${ }^{19}$

\footnotetext{
${ }^{14}$ Șadrā,Tafsīr Al-Qur'ān, J. 7, 373.

${ }^{15}$ Șadrā, Majmū at al-Rasā'il al-Tis 'ah ( a Collection of 9 Treatises), (Tehran: --), 347, 359; Șadrā, Al Hikmah ..., J. 9, 246.

${ }^{16}$ Șadrā, Mafätih al-Ghayb, (Tehran: Cultural Researches Institution, 1982), 114.

${ }^{17}$ Șadrā, Tafsīr Al-Qur'ān ..., J. 7, 387.

${ }^{18}$ Ibid., J. 7, 388.

${ }^{19}$ Șadrā, Mafātih ...,115.
} 


\section{The Relation between Doer ( $f a$ ' $\left.^{\prime} i\right)$ and Action ('amal) with Ma'âd}

The ethical consequence of Mulla Șadrā's eschatological theory (as discussed above) is that Sadrā invites us to make improvements to the act of ethics and to direct will (irādah) to the nobler end, continuously through worship recommended by religion, Worldly life and improve morals. The purpose of that is so that we can realize (happiness) the happiness of the world and hereafter. It is one of the metaphysical dimensions of human ethical acts. In some of his several treatises of tafsir and philosophical work, others Șadrā emphasize similar things. All the charities, actions and goals we have during our life in the world will be picked up in the future. ${ }^{20}$

The Qur'an also describes such things, for example in QS. Yasin / 36: 54, QS. Ath Thuur / 52: 16, QS. Fushshilat / 41: 28. Related to the relationship between the charity and the culprit, we can explain it with the help of Kamāl al Haydar deskripsi description as follows ${ }^{21}$ :

The first phase is called $h \bar{a} l$ (potential). This phase is a certain condition that someone has to perform an action, but the condition is easily lost. The second phase is called possessive (malakah). This is a phase in which the strength of existence and consciousness increases, making it more difficult to separate love from an action ('amal) with the perpetrator. The third phase is called union (ittiha $\bar{a}$ ). This is the phase where the malakah above has become part of a human being that is impossible to separate it. This is the initial stage of infallibility (waking).

The three levels of interrelationship between the deed and the culprit can be understood from the point of view that the soul originates from the jismāniyah (matter) then fits perfectly with the motion of the substance up to the abstract level (stage) of matter. Based on the principle of motion of substance (al harakah al jauhariyah), the body is the access to enter the identity (huwiyah) soul that will walk towards the path of perfection or vice versa (imperfection). The principle of motion of this substance is due to the existence of a strong bond between the soul and the body, namely a relationship (relationship) in the identity of his soul not on the quidity.

So, as discussed earlier, we know that the attachment between charity, good deeds or bad deeds, with the culprit has three stages as above. All good deeds such as prayer, fasting, zakat and infaq have inner and dhohir sides. The dhohir side is the practice, while the inner side is heaven or hell. If it has united between the charity and the perpetrator then the perpetrator (human) is the paradise (or hell) itself.

When someone does a deed, then the practice will unite with it. As in the motion of the substance (harakahjauhariyyah), the subject of the perpetrator will unite with the action (charity) it. The perpetrator is the charity itself. The charity will also manifest in the day akherat later. The evil act will be a fire (hell). As the Qur'anic verse states that:

\footnotetext{
${ }^{20}$ Șadrā, Asrār al- 'Ayāt, (Tehran: Theosophy Philosophy Association, 1981), 205.

${ }^{21}$ Kamāl al-Haydarī, al Tarbiyah al Rūhiyah: Buhūth fì Jihād al Nafs, (Iran: Dār Farāqid), 136-140.
} 


$$
\text { إن الذين يأكلون أموال اليتامى ظلما إنما يأكلون في بطوفم نارا وسيصلون سعيرا }
$$

"Indeed, those who eat the wealth of the orphans in tyranny, in fact they are swallowing the fire full of their stomachs and they will enter into a fiery fire (hell)." (Surat An Nisaa / 4: 10)

The act is inherently a meal of the orphan's property, but in his/ her inner side of body he/she consumes fire. This kind of action will be visible on the Day of Judgment.

\section{The Relation between Akhlāq and Ma'àd}

As explained earlier, Șadrā divides the human soul into three kinds of perceptions related to the ethical side of all human actions; first, Sensory perceptions which are the outward senses or commonly referred to as the world implied by the potential Intellect (al'aql bi al quwwah). Second, Imaginary perceptions which is the inner sense commonly referred to as the afterlife. This type of perception is represented by possessive Intellect (al'aql bi al malakah). It is divided into two parts: heaven and hell that determine whether humans become happy or unlucky. Of course, it will depend on his ethical actions. The third type is an intellectual perception whose manifestation is intellectual potential and when he becomes the actual intellect (al'aql bi al-fi'it), he becomes pure happiness and kindness (khair maḥ̣an). Șadrā mentions the first type referred to as the potential locus, whereas the second and third types are referred to as the actual locus. The first type is called a seed while the second and third species are called fruit and agricultural products. ${ }^{22}$

In the theoretical faculty, one will be able to distinguish between the haq and bātil, the good and the whole with respect to universal intellectual objects. Whereas in the faculty of practice one will have a world view in all his ethical actions that will be represented in all particular cases; Something that should be done and abandoned. He will be able to distinguish between good and bad in every action. Faculty of practice serves and perfects theoretical faculty. Therefore, with these two faculties the soul will reach its perfection. ${ }^{23}$

The two potentials are a unity. His knowledge becomes action, and his actions become knowledge. This unity becomes unity as is aligned with one of the philosophical principles of Șadrā 'unity between action and actor (ittihād al 'amal wa al 'àmil) ${ }^{24}$. So that a person will be disifati as a fair and wise because he has achieved the two wisdom (theoretical faculties and practice) simultaneously; When his soul has perfected the two potentials into a single potential. When perceiving the perfection of the theoretical faculty as well as the practice perfectly without being attached to the body, then he will feel happiness.

Knowledge (ma'rifah) is the seed of witnessing as it applies to the seed. Certain plant seeds will produce plants and fruits in particular. The stronger the knowledge that human

\footnotetext{
${ }^{22}$ Șadrā, Al Hikmah ..., J. 9, 21-22.

${ }^{23}$ Ṣadrā, Al Shawāhid al Rubūbiyah fì al Manāhij al Sulūkiyah, (Mashhad: al markaz al jami’I li al nashr, 1981), 200.

${ }^{24}$ Ibid., 200.
} 
beings achieve in the world, the more witness they can get stronger. And conversely, if the weaker the knowledge, the penyaksiaannya will be weaker. ${ }^{25}$ Sadrā affirms: "wherever a man who knows not God in this world will witness him in the future" (Q.S. al Isro '(17): 72). The statement of Sadrā is Al Qur'an Surah Al Israa 'verse 72.

$$
\text { ومن كان في هذه أعمى فهو في الآخرة أعمى وأضل سبيلا }
$$

"And whoso is blind in this world, in the Hereafter he shall be more blind and more lost from the way" (Surat al-Israa '/ 17: 72).

Thus, the Knowledge of God in this world will give such a glorious pleasure when the opening of all hijabs in the future will be. From this, it becomes clear that happiness in the view of Sadrā is identified with perfection and goodness. To achieve it of course with the perfection of being, and the way to achieve it is stored in the perception of the soul and self-consciousness.

The level of intellectual perception intended by Șadrā to achieve ultimate happiness is not related to particular sciences such as nahwu, sarf, engineering, sewing skills and other types, but the sciences related to God, His attributes, angels, And the reality of nature. The happiness of knowledge (knowledge) depends on the degree of its glory. In accordance with Șadrā's view that the glory of knowledge depends on the glory of the object of knowledge $\left(m a^{\prime} h \bar{h} m\right) .{ }^{26}$ And certainly, in the reality of this being, there is nothing nobler and greater than God, His attributes, angels, the reality of nature, His book and His ruling. Thus it becomes clear that this kind of knowledge is an ultimate pleasure and happiness. Thus, the ultimate enjoyment of knowledge (knowledge) is certainly the knowledge associated with God, șifăt, 'af'âl and tadbīr (arrangement) Him to the universe. It is this kind of knowledge that has been achieved by the prophets, wise men (hukamā') and 'urafá. ${ }^{27}$

Nevertheless, according to Sadrā, the ultimate happiness for man will be realized in the perfection of the potential of the soul after the release of the soul's relationship with the unsuurī body through the path of death. The theory of Șadrā is in harmony with anhadīth: "Whosoever dies, then has his eral end (al qiyāmah al șughrā)". After death the soul will return to its essential essence. We will not be able to naturally indulge in happiness and pleasure. $^{28}$

"... Science is the consummation of the spirit, while the deed is the perfect of the body ... The substance of the spirit is more noble than the substance of the body. Hence the pleasure and perfection is more noble (ashraf) than the perfection of the body. Pleasure about ma'rifatullah is more noble than the pleasures associated with the pleasures of food, lust of marriage and the beauty of clothing ... ". ${ }^{29}$

\footnotetext{
${ }^{25}$ Șadrā, Tafsīr Al-Qur'ān ..., J. 7, 398.

${ }^{26}$ Șadrā, Kasr al Așnām al Jāhiliyyah, (Tehran: Bonyad Hikmat-e Islami Sadra Publishers, 2002), 235.

${ }^{27}$ Ṣadrā, Tafsīr Al-Qur'ān ..., J. 7, 397; Șadrā, Kasr al-Aṣnām ..., 235.

${ }^{28}$ Șadrā, Al-Hikmah ... , J. 9, 121; Șadrā, Al-Qur'ān ..., J. 7, 398.

${ }^{29}$ Șadrā, Tafsīr Al-Qur'ān ..., J. 7, 397.
} 
When released from the body, the soul becomes fully actual and knowledge of the soul will appear as it is. And why can not we see that reality nowadays, even though the world has existed today? This is because it is blocked by hijab. The veil will be lifted with death. Sadrā affirms: "The veil between us and God is the world. Our world is preoccupied with the attachments of low worldly matters (which will vanish) ". ${ }^{30}$

Next, how the ways and processes to get happiness are? Sadra emphasized the importance of soul training, that is, by actions and charities that can support that perfection; By avoiding all things that memaj (contaminate) the soul so that he is able to perceive the forms of everything and its quantity well. The effort of tazkiya al nafs becomes important because the suffering felt by human is caused by immoral actions and leave obedience. Șadrā states:

"When the human mind ta'at and devoted to the three power, then essentially like a man who devoted to shetan, dog or pig. If throughout his life he does not return to keta'tan with repentance from such exaggeration (tafrìt) then his position is less than animal; 'They are like cattle, or even more perverted' (Q.S. Al a'raf (7): 179)."31

Why did it happen? Why suffering can arise? Suffering can happen because the submission of mind to the lower powers of it. Submission of reason to syawhat or anger. This is one form of ignorance (jahl). Therefore, Sadrā states: "... the base of all good is knowledge of all reality and charity against it, while the base of all ugliness is ignorance and every action directed to lust and anger ..."32. If a person during his lifetime is not immediately aware of the ignorance and does not immediately return (repent) then the level (manzilah) is less than animals. Such a contemptible position may be attributed to him because the servant of something is lower in position than the one served and the purpose. ${ }^{33}$

They are all physical attraction of the potentials of wahmiyah, shahwiyah, and ghadabiyah (rage) rather than rational potential. If this happens, then the physical potential will dominate the rational potential ('aqliyah). And if this continues, it will make the soul's strongest desire to the world and weaken for love in the affair. ${ }^{34}$

One of the secrets and purposes of worship or of all religious activities which is prescribed is to make the physical body, the physical organs, and the natural instincts to submit to reason so that strong will and determination can control the lust and force the body to act in accordance with the will Reason, and prevent it from all things that violate the mind ${ }^{35}$ Sadrā states:

\footnotetext{
${ }^{30}$ Ibid, 398.

${ }^{31}$ Ibid., J. 7, 393.

${ }^{32}$ Șadrā, Mafātih al-Ghayb, (Tehran: Cultural Researches Institution, 1982), 195.

${ }^{33}$ Șadrā, Tafsìr Al-Qur'ān ..., J. 7, 393.

${ }^{34}$ Ibid., J. 7, 394.

${ }^{35}$ Șadrā, Al-Shawāhid al Rubūbiyah ..., 368.
} 
"The afterlife is the foundation for every happiness, whereas the love of the world (hubbu aldunyā) is the base of error (ra'su kulli al khatī'ah). ${ }^{36}$ The sign of the absence of knowledge ('alāmatu'adami'irfān) is the absence of the love of meeting ('adamu ubub al liqū ), and the sign of the absence of love ('alāmatu'adami al ḥub) ie the hatred of death (karāha al-maut) and prefers ('ithār) to the life of the world." ${ }^{37}$

When reason dominates the body, the physical organs will be under the control of the mind so that whatever the mind of the body wants will be done without any objections and obstacles. Among the advantages and secrets of hard worship and exhausting observance exercises is that they help achieve that goal. Therefore, Șadrā states that: "the peak of suffering lies in ignorance (jahl)." 38

The reason why someone can prefer (prioritize) the life of the world than akherat? It is because of ignorance (jahl) and hardness of heart. Such a person is likened to Sadrā likes a person whose limbs are cut (imperfect). So when one has reached a stage so as to perceive the divine knowledge (idrāk al ma'rifah al ilähiyah) then surely he will enjoy that knowledge. And there will come the love (desire) to meet (liqā ') with God and witness His Dhāt with intellectual vision. ${ }^{39}$

Oppositely, the sign of the absence of knowledge is the absence of love for liqā '. Another sign is the emergence of hatred towards death and more priority to the life of the world. ${ }^{40}$ Signs of ignorance and the absence of such essential knowledge are hinted at by the Qur'an:

$$
\text { قل يا أيها الذين هادوا إن زعمتم أنكم أولياء لله من دون الناس فتمنوا الموت إن كنتم صادقين }
$$

"Say: O ye who practice the Jews, if ye claim that ye are the beloved of Allah not the other men, so expect your death if ye are truthful." (Surat al-Jumu'ah / 62: 6)

Thus, it is a review of happiness from the theoretical sense, while from the practical side that is by implementing ethics (akhlāq) is good and away from the contemptible things. The ultimate happiness will not be realized except with the realization of ethical happiness first. If both manifest, then the person attains ultimate happiness. ${ }^{41}$ This is because the happiness of the as mentioned above demands two aspects, namely from theoretical aspects ('ilmiyyah) and practice ('amaliyyah).

The happiness of ethics can be proven by the actualization of justice (equilibrium) in all actions. Justice itself can be realized by the nature of the middle; Not extremism, guluw and exaggeration (ifrät) or less overt and lazy (tafint). Controlling the three

\footnotetext{
${ }^{36}$ Ibid., 368.

${ }^{37}$ Șadrā, Tafsìr Al-Qur'ān, J. 7, 400.

${ }^{38}$ Ibid., J. 7, 387-388.

${ }^{39}$ Ibid., J. 7, 399.

${ }^{40}$ Ibid., J. 7, 400.

${ }^{41}$ Șadrā, Al-Hikmah al-Muta 'āliyah ..., J. 9, 131.
} 
potentials of the human soul; Lust, anger and thinking so that gave birth to moral virtues such as self-esteem ( 'iffah), courage (shajā'ah) and virtue (hikmah). ${ }^{42}$

The nature of the middle is in harmony with the principle of choice (ikhtiyār) man. Sadra holds that all human actions are not passive (jabr) or free (tafwīẹ). But it is positioned between these two things ('amrun bayna amrayn), ${ }^{43}$ namely the ability, the will, the science, and the desire to do something that belong to human beings are the near term for a human action. But all will lean (connect) with other causes as intermediaries so that will arrive at the will, knowledge, qadā 'and qadar of God.

Șadrā describes the level of achievement of the human soul (as explained before) that there are people who have a holy soul like the prophets so they do not need human teaching. There are also people whose souls are so weak that they desperately need other human teachings to gain knowledge (knowledge). And there are also people who have stupid and stupid souls that will not be useful even though they have received instruction, despite the teaching of a prophet. ${ }^{44}$

Since most humans do not attain holy mujah as in the prophets and holy guardians, there is no way for them except by believing, accepting and justifying what the faithful givers of the Lord bring. As for a group of people who are not only satisfied with the condition, and want to get directly through revelation or through argumentation (burhān), they must strive and do jihād fī nafs. Since this path is not an easy path, they should try to do the purification of the soul (tazkiyah al nafs); Soften the soul, purify the substance of his soul and mind (theoretically and practice). ${ }^{45}$

If realized the freedom and wisdom in all human actions, namely the potential of science, anger, lust and intellect. The balance and harmony of the whole potential will produce noble qualities. Alignment in the potential of knowledge (knowledge) will make it known to distinguish truth and lies in words; between haq and falsehood in belief; Between good and bad in action. If balanced and harmonious of the overall potential (not ifrāt or tafint $)$, it will obtain the fruits and the essence of goodness, that is, hikmah. ${ }^{46}$ Sadra also names the mid-nature as a straight path (al sirāt al mustaqīm). Islam appeals to every human being to go straight. Straight path (al sirāt al mustaqīm) is often likened to a road that is thinner than hair or sharper than a knife. ${ }^{47}$

While justice (from the aspect of charity) as meant by Sadrā is mid between two ends that lies between two bad traits, that is exaggeration in action (ifrāṭ) or laziness (tafrìt). So, mid and justice is a straight path (al sirāt al mustaqīm). So whoever wished to

\footnotetext{
${ }^{42}$ Ibid., J. 9, 127.

${ }^{43}$ Ibid., J. 6, 375-376.

${ }^{44}$ Ibid., J. 9, 87; Șadrā, Tafsīr Al-Qur'ān, J. 7, 373-375.

${ }^{45}$ Șadrā,Tafsìr Al-Qur'ān, J. 7, 403 - 404.

${ }^{46}$ Șadrā, Al-Hikmah al-Muta 'āliyah ..., J. 9, 88 -89.

${ }^{47}$ Șadrā, Asrār ..., 191-192.
} 
defeat his lust, his mind was able to become a leader for lust, then he would become more important than the angels. And conversely, if the mind is confined and imprisoned by lust, lust becomes the leader of his mind then he will become more heretical (contemptible) than cattle. So, with theoretical sense we can see it carefully (the straight path), whereas with the common sense, we are able to control and mediate the sides of lust, anger and reason in our actions.

The prophets were not commanded to kill these forces, but for control and subjection of all that power under the command of reason and the laws of God. Because, each of those forces wants to do its work and achieve its own goals even if it is not controlled it will cause damage and chaos in human beings.

The prophets came to this world with various laws and celestial books so that man could avoid the overwhelming nature and indolence of his instincts, and in order to subdue, train and educate himself under the control of the laws of reason and shari'a. Thus, any individual who is able to print his character in line with God's laws and rational principles will be lucky and obtain salvation. Thus, the primary purpose of the whole prophets and the Prophets is to return to two things, namely the release of all the attachments of the material of the world (al-tajarnūd 'an al-'alā'iq) and the consummation of the soul (al istikmāl bi al haqā'iq). ${ }^{48}$

Through the restrictions, all human actions in this world will be judged in the future; Whether he will get a reward or punishment. This is because in his nature, there is a demand to walk in the path (sirāt). If the action is good, doers will get a reward in heaven, whereas if the action is bad (contemptible) then it will get the punishment in hell. Such provisions are consistent with his commitment to his ethical review.

Although Șadrā divides happiness into two aspects ('ilmiyah and'amāliyah), however, in tafsīr Q. S. al 'a'la, Sadra prefers the theoretical aspect ('ilmiyya) rather than the practice aspect ('amāliyah). For example, we can see from the following Sadrā statement: "The worst of evil is to follow ignorance (al jahl al murakkab), whereas the best good is to follow the science. The stupidity of stupidity is greater than that of bodily harm." 49

Șadrā also emphasizes the importance and benefits (fâ'idah) of various religions such as prayer, fasting, zakat, pilgrimage and various other worship. According to him, the worship services have an influence on the soul. Such taklif helps to release and free the soul from imprisonment; Keep him away from disobedience; Purify it; Help sulūk in the path of akherat and keep it away from the world's heaviness and all its trimmings. On the contrary, all charities and bad acts (which are forbidden by religion) will surely have a negative effect, which will darken the substance of the soul, bind the soul to the world and all its

\footnotetext{
${ }^{48}$ Șadrā,Tafsìr Al-Qur'ān ..., J. 7, 402.

${ }^{49}$ Ibid, , J. 7, 387.
} 
lust. Positive or negative effects that are still covered in the world will be revealed in the future. ${ }^{50}$

From that description, religious rituals that are shari'ed by religion are not only limited as mere obligations, but contained in them the meaning of ethics (akhlāk) and its effect on the mukallaf. The ultimate goal of worship ritual is to cleanse the soul. Sadra states:

"Charity and training (riyāzah badāniyah) such as prayer, zakāt and other charitable deeds have the purpose of escaping (soul) from sensual accidents (al 'a'rāọ al hissiyah), freed from material dark matter, the opening of perceptive potentials, All of it so that he can become accustomed to rise from the mortal to the realm of happiness; From sources of destruction and injustice to the source of life, mercy and light." ${ }^{51}$

The movements of physical worship such as prayer, fasting and pilgrimage can cure laziness and not ta'atnya body against a weak soul. To treat the disease, naturally, one must train oneself by doing things contrary to the condition.

According to Sadra, prayer is the best worship body because in it contained the most important spirit that is ma'rifah on God. ${ }^{52}$ Prayer serves to prevent a person from misconduct (fakhshā ') and munkar. Prayer is also a worship that includes all the essential elements of the body and soul, for example from cleansing and purifying, khuḍu 'and khushū', straightening the intention, drawing closer to God, dhikr and praise to God, and the guidance of reciting the Qur'an. ${ }^{53}$

In fasting, in addition to hunger and abandoning prohibited ugliness during fasting ritual, one is trained to solve the potential of excessive lust; And instead trains him to hold fast to all that God has commanded. ${ }^{54}$ Though outwardly, the fast appears silent, but this kind of worship moves hard on the inner side, that is, by causing the need to seek knowledge and seclusion to a higher position. ${ }^{55}$

While at the pilgrimage, one will be trained to take tawajuh / facing towards the baitullah with a sincere intention; To abandon all the pleasures and lusts of animals; Abstracting themselves from all the potential of the body and its pleasure, drawing closer to God with all obedience. With zakat, one is trained to purify his soul from the love of wealth; Cleansing of the nature of bakhīl; Help and give the wealth to the poor. ${ }^{56}$

Based on the structure and explanation above, it is known that humans are composed of two substances; between dead and silent forms and matter; soul and body;

\footnotetext{
${ }^{50}$ Șadrā, Asrār ..., 213.

${ }^{51}$ Șadrā, Tafsīr Al-Qur'ān ..., J. 7, 390-391.

${ }^{52}$ Șadrā, Mafātih ..., 289.

${ }^{53}$ Șadrā, Al-Shawāhid ..., 368-369.

${ }^{54}$ Ibid., 369.

${ }^{55}$ Șadrā, Tafsīr Al-Qur'ān ..., J. 7, 392.

${ }^{56}$ Șadrā, Al-Shawāhid ..., 369 - 370.
} 
patience and anger. Every lust and physical delicacy is the source of ugliness. If both defeat and subdue the soul of thinking (al nafs al nătiqah), and make the lust and lust as an offering. And with the whisper of ammāratus bil sū 'so that adorn themselves with the unrighteous deeds and the humility of the humble, thus causing the soul to get lost and in the doom in the future. ${ }^{57}$

Thus, it is impossible for us to escape from such devotion of the world unless the soul of thought (al nafs al nātiqah) defeats (over) the lust of shaytāniyah. The soul of thinking (al nafs al nātiqah) avoids immorality, and encourages it to do the principal deeds (fâdịlah), perform obedience and worship according to the Shari'a, faith in the case of the hereafter. ${ }^{58}$ Therefore, it is mandatory for humans to evaluate themselves and the deeds that have been performed.

\section{Conclusion}

In Mulla Sadrā's view on eschatology, there are several important points that we can conclude: First, Mulla Șadrā emphasizes science (makrifat). According to him, Divine Proximity (the divine qurb) and the ultimate happiness of man can not be achieved without the science (makrifat). In addition, he also emphasizes charity and worship. Charity and worship are rides (wāsilah) for that purpose. Thus, happiness will be strongly influenced by the balance of actualization of two human faculties; Balance of theoretical and practical sense.

Second, Science and charity while living in the world will give effect to our soul in akherat one day. The shape (form) of every human being in the future will be in accordance with his knowledge and charity in the world. Thus, Science and charity is a reflection of the soul. Both have a great influence on the soul.

Third, Mulla Șadrā's Eschatology Philosophy has implications for ethics. The knowledge (knowledge) of human beings against various tortures akherat will give effect for him to reduce (know) all ugliness. Knowledge (knowledge) will be the reins of the actions of bad, and at the same time will be a driver to do good deeds to realize happiness akherat. Belief in the existence of the awakening will give a great influence on human morality. A person will make his behavior in the life of the world in harmony with his life akheratnya. This kind of belief will make it committed to religious matters and subject to religious ethical standards. Thus, Mulla Șadrā's ethics as an implication of his eschatological philosophy is synergistic with the main sources of religion; Both the Qur'an and the Hadith of the Prophet.

\footnotetext{
${ }^{57}$ Ibid., 371.

${ }^{58}$ Ibid., $373-374$.
} 


\section{Bibliography}

Amuli, Jawadi, Makna Hari Kiamat Dalam Al Qur'an, Jakarta: Sadra Press, 2012.

al Ḥaydarī, Kamāl, al Tarbiyah al Rūhiyah: Buhūth fì Jihād al Nafs, Iran: Dār Farāqid.

Hude, M. Darwis, Logika Al Quran (Pemaknaan Ayat Dalam Berbagai Tema), Jakarta: EURABIA, Januari 2015.

Khamenei, Muhammad, Mulla Sadra's Transcendent Philosophy, Tehran: Sadra Islamic Philosophy Research Institute (SIPRIn), $2004=1383$. , the Qur'anic Hermeneutics of Mulla Sadra, Tehran: SIPRIn Publications, $2006=$ 1385.

, “Exegesis Fundamentals and Qur'anics for Mulla Șadrā”, dalam SIPRIñmullaṢadrā .org.

Nasr, Hossein, Ensikolpedi Tematis Filsafat Islam, Translated from: History of Islamic Philosophy, Bandung: Mizan, 2003.

, Islamic Philosophy from Its Origin to the Present: Philosophy in the Land of Prophecy,

New York: State University of New York Press, 2006.

, "the Qur'an and Hadith as Source and Inspiration of Islamic Philosophy".

Man and Nature: The Spiritual Crisis in Modern Man, Chicago: KAZI Publications, 1997

Nur, Muhammad, Takwil dalam Pandangan Mulla Sadra, in Kanz Philosophia: a Journal for Islamic Philosophy and Mysticism, vol. 2, no. 2, December 2012.

Rustom, Mohammed, Qur'anic Exegesis in Later Islamic Philosophy: Mulla Sadra's Tafsīr

Surah al- Fätihah, University of Toronto, 2009.

, ‘the nature and significance of Mulla Șadrā's Qur'anic Writing”.

Șadrā, Mohammad al Shīrāzī, Al Ḥikmah al Muta'āliyah fì al Asfãr al 'Aqliyah al Arba'ah, Beirut: Dār ihyā' al turāth, 1981.

, Al Mażāhir Al Ilāhiyyah fì Asrār al 'Uhūm al Kamāliyyah, Tehran: Bonyad Hikmat Sadra Publishers.

,Al Shawāhid al Rubūbiyah fì al Manāhij al Sū̄kkiyah, Mashhad: al markaz al jami’I li al nashr, 1981.

, Asrār al 'Ayāt, Tehran: Theosophy Philosophy Association, 1981.

,Kasr al Aṣnām al Jāhiliyyah, Tehran: Bonyad Hikmat-e Islami Sadra Publishers, 2002.

,Mafãtịh al Ghayb, Tehran: Cultural Researches Institution, 1982.

,Majmū 'at al Rasā' 'il al Tis'ah (a Collection of 9 Treatises), Tehran: --.

, Tafsìr Al Qur'ān al Kan̄m, Qum: Intishārāt Bīdār,1344 H.

Shihab, M. Quraish, Perjalanan Menuju Keabadian: Kematian, Surga dan Ayat-Ayat Tahlil, Jakarta: Lentera Hati, 2002. 
Sibawaihi, Eskatologi Al Gazali dan Fazlur Rahman: Studi Komparatif Epistemologi Klasik-Kontemporer, Yogyakarta: Penerbit Islamika, 2004.

Tabātabā'I, M. Husein, al Mizzān fi Tafsir al Qur'ān, Qum: Mu'assasah al Nasr Al Islamy, $1417 \mathrm{H}$.

Al Walid, Kholid, Perjalanan Jiwa Menuju Akhirat: Filsafat Eskatologi Mulla Shadra, Jakarta: Sadra Press, 2012

Yazdi, M. T. Mishbah, Iman Semesta: Merancang Piramida Keyakinan, Jakarta: Al Huda, 2005. 